\title{
院内製剤レバミピド注腸剤の安定性試験と有効を示した臨床例
}

\author{
森 $\quad$ 健 ${ }^{*} \dagger^{1}$ ，宮田充樹 $\dagger^{2}$ ，小宮山恵 $\dagger^{1}$ ，大西正文 $\dagger^{1}$ ，岡田 啓 $\dagger^{1}$ \\ 愛知医科大学附属病院薬郕部门 \\ 愛知医科大学消化器内科 $\dagger^{2}$
}

\section{Stability Study of a Rebamipide Rectal Suspension Enema and a Clinical Case Showing a Good Response}

\author{
Takeshi Mori ${ }^{*} \dagger^{1}$, Mitsuki Miyata $\uparrow^{2}$, Megumi Komiyama $\dagger^{1}$, \\ Masafumi Ohnishi $\dagger^{1}$ and Hiroshi Okada $\dagger^{1}$ \\ Department of Pharmacy, Aichi Medical University School of Medicine $\dagger^{1}$ \\ Department of Internal Medicine (Gastroenterology), Aichi Medical University School of Medicine $\dot{\dagger}^{2}$
}

\author{
$\left[\begin{array}{l}\text { Received June 29, } 2002 \\ \text { Accepted January 25, } 2003\end{array}\right]$
}

Rebamipide, an antiulcer drug, has been reported to possess an antioxidant effect and to restore the impairment of antioxidants in experimental colitis. Recently, a rebamipide rectal suspension enema has been investigated as one type of pharmacotherapy to treat ulcerative colitis (UC). This enema has been prepared in-house, but its stability has not yet been examined. In our hospital, we prescribe a drug for which its stability is unknown for only a short period. This enema could not be prescribed with other drugs that could be prescribed for a longer period. As a result, such patients have come to the hospital frequently, which makes the treatment regimen more difficult. We determined the contents of rebamipide contained in the enema using HPLC, and observed no significant changes after 5 weeks of storage, which thus made its longer-term prescription possible. We also experienced a patient with moderate rectal UC who encountered adverse effects related to steroid treatment. While tapering the dosage of steroids, we administered the rebamipide rectal suspension enema, and the patient responded well to the agent.

Keywords — rebamipide rectal suspension enema, stability test, HPLC, ulcerative colitis

\section{はじめに}

炎症性腸疾患の一つである潰瘍性大腸炎(UC) は，主 として大腸の粘膜を侵し，しばしばびらんや潰瘍を形成 する原因不明のびまん性非特異性炎症 ${ }^{1)}$ である。UCの 主症状は, 下痢, 粘血便, 腹痛, 頻脈, 発熱である. 活 動期にあるUCの軽症・中等症に対する薬物治療は, サ ラゾスルファピリジン (SASP)や5-amino salicylic acid
（5-ASA）が第一選択薬となる。中等症・重症には，副 腎皮質ホルモン剤(ステロイド剤)などの経口あるいは直 腸内投与を用いるが，寛解導入後も時期を置いて再燃を 繰り返すことが知られている。再燃を繰り返しながら炎 症範囲が肛門側へ進展し, 難治化する例も少なくない. 難治例では, ステロイド剤の大量静注療法が行われ，そ の無効例に対しては外科的療法に移行する場合がある. ステロイド剤は副作用も多く, ステロイド依存性, 抵抗 
性, 離脱困難例などには新しい治療法が模索されている. レバミピドは胃炎・胃潰瘍治療薬として広く臨床使用 されているが, 薬理作用の一つに活性酸素に対する作 用, ヒドロキシラジカルの消去作用, 多核白血球のスー パーオキシド産生抑制作用を有し2,3)，1996年 Zea-Iriarte ら゙)は，ラットの Trinitrobenzene sulphonic acid(TNBS) 腸炎において抗酸化機構異常の改善作用があることを見 出した。一方 Makiyama ら ${ }^{5}$ はUC患者に対して, レバミ ピド $150 \mathrm{mg}$ と $1.5 \% \mathrm{CMC}-\mathrm{Na}$ の懸濁液 $60 \mathrm{~mL}$ を作製し, 朝 夕 2 回注腸した臨床的効果を報告し，また宮田ら而も， 同懸濁液にて臨床的有効性を報告している。

当院ではレバミピド注腸液を院内製剂として薬剤部で 調製し, 治療に供している。しかし製剤後の安定性につ いては報告がないことから，今回われわれは高速液体ク ロマトグラフ(HPLC) 法を用いてレバミピド注腸液の経 時的な安定性試験を行い，知見を得たので報告する。ま た臨床応用例のうち, 中等症直腸型 UC の治療に用いら れていたステロイド剂で副作用が生じ, その離脱のため にレバミピド注腸療法を試み, 有効であったと考えられ た 1 症例を報告する。

\section{実験方法}

\section{1. 材料}

実験に使用したレバミピド(ムコス夕錠100)と生理食

表 1.レバミピド注腸液の処方 (1 回分)

\begin{tabular}{ll}
\hline ムコスタ錠100 & 1.5 錠(レバミピド150mg) \\
カルボキシメチル & $0.9 \mathrm{~g}$ \\
セルロースナトリウム & \\
生理食塩液 & 全量 $60 \mathrm{~mL}$ \\
\hline 以上をオーエネマ60に充填し, 1 日2回直腸内投与する
\end{tabular}

塩水は大塚製薬(株より購入し, カルボキシメチルセル ロースナトリウムはシグマ社より購入した。

\section{2. ムコスタ注腸液の調製方法}

注腸液の処方内容を表 1 に示した。調製は, 生理食塩 水にムコスタ錠100を加え, 十分に分散するまで攪汼し た。次にカルボキシメチルセルロースナトリウムを加え て攪汼し，生理食塩水を加え十分に攪拌した。この懸濁 液を試験に供した。

\section{3. 定量と操作条件}

定量方法のフローチャートを図 1 に示した。試料溶液 および標準溶液 $20 \mu \mathrm{L}$ について, 内標準法によりレバミ ピドの含量を求めた.HPLCの操作条件を表 2 に示した.

\section{4. 保存条件とサンプリング}

保存条件は $25^{\circ} \mathrm{C} \cdot$ 遮光, $10^{\circ} \mathrm{C} \cdot$ 遮光の 2 条件とし, 保 存期間は 5 週間とした。サンプリングは, 開始時, 1 週 目， 2 週目，4週目，5週目とした. 調製時の懸濁液を開 始時分析試料とし，1週目以降のサンプリングは，懸濁 液を十分に振とうしてから約 $50 \mathrm{~mL} \times 3$ を採取し試料と した。この懸濁液を攪找しながら試験用試料を採取した。

\section{結果}

\section{1.レバミピド注腸液の外観}

調製した液は白濁した懸濁液である。いずれの保存温 度においても試験期間中, 粒子が沈降した以外の変化は 認められなかった。 また, 沈降した粒子は再分散性に優 れていた。

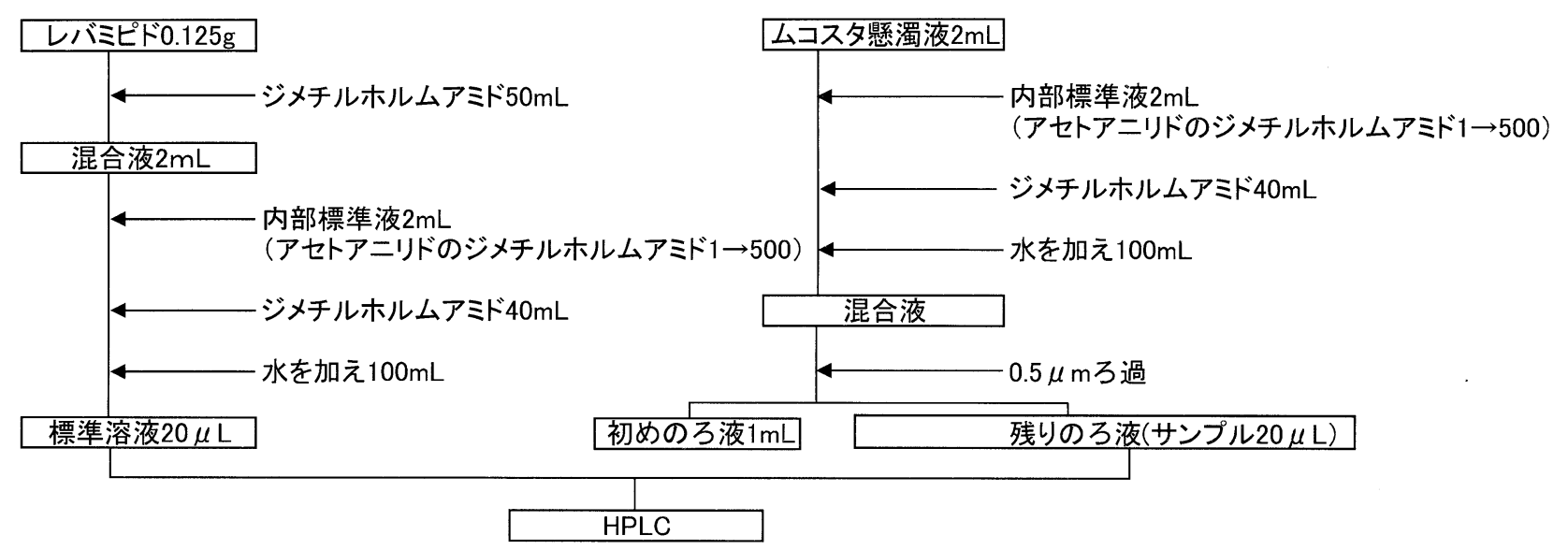

図 1. 定量方法のフローチャート 


\section{2. $\mathrm{pH}$ 測定結果}

レバミピドの経時的 $\mathrm{pH}$ を図 2 に示した。試験期間中 いずれの保存条件でも大きな変化はなかった。

\section{3. 定量結果}

経時的なレバミピドの含有量を図 3 に示した。開始時 を $100 \%$ とし, 残存率として示したが, いずれの保存条

表 2. HPLC の操作条件

\begin{tabular}{ll}
\hline 検出器 & 紫外可視吸光光度計 $(254 \mathrm{~nm})$ \\
カラム & TSK gel ODSー80Ts 4.6X150mm \\
カラム温度 & 室温付近の一定温度 \\
移動相 & 17\%アセトニトリルを含むリン酸緩衝液 \\
流量 & 保持時間が約20分になるように調整 \\
\hline
\end{tabular}

件においてもほとんど変化はみられず，試験期間中安定 であった。

\section{症例報告}

\section{1. 症例}

提示する症例は，33歳の女性で職業は事務員である. 主訴は血便，腹痛であり，既往歴および家族歴に特記す ベき事項はなかった。

\section{2. 現病歴}

平成 9 年 1 月頃より下腹部痛, 下痢が出現し, 近医に 受診し感冒性腸炎と診断され，投薬を受けたが改善はみ られず，2月初めから血液付着便もみられるようになっ たため当科を受診した。精査の結果, 中等症直腸型潰瘍 性大腸炎と診断された. 外来で5-ASAを $2250 \mathrm{mg} /$ 日投

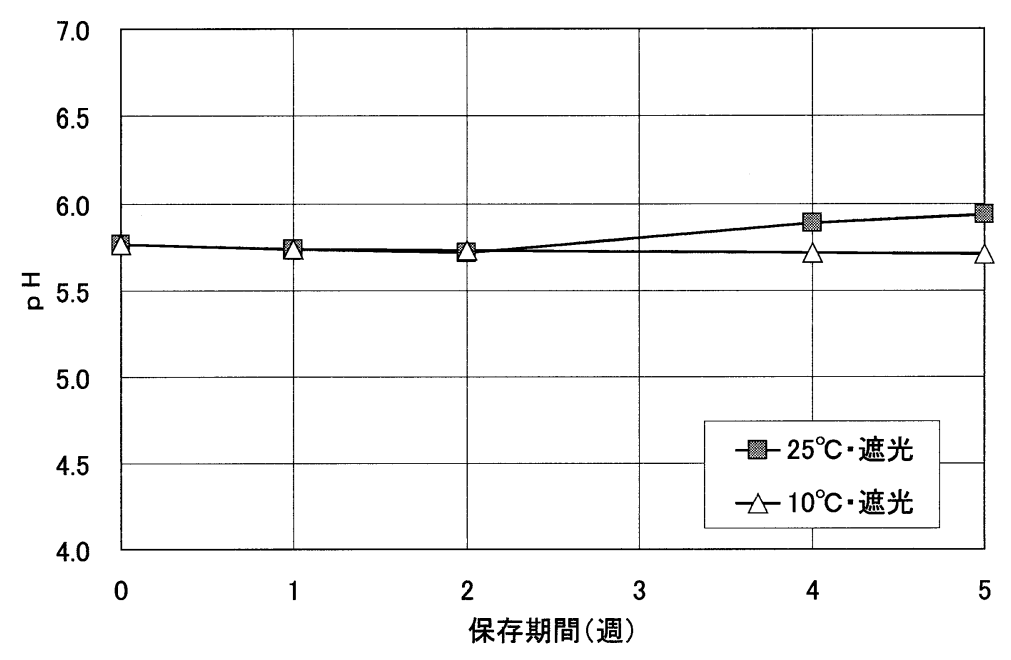

図 2.レバミピド注腸液の $\mathrm{pH}$ 変化

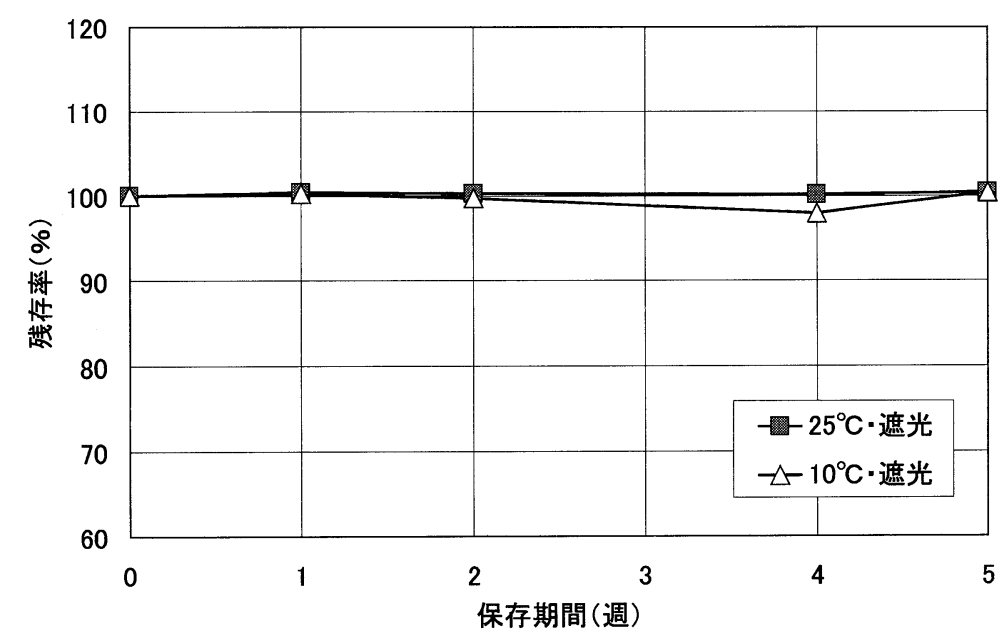

図 3. 注腸液中におけるレバミピドの残存率 
与したが改善はみられず，ステロイド注腸剤(ステロネ マ)を加え症状は寛解状態となった。投薬開始後 2 力月 後より満月様顔貌, 顔面・後背部に尋常性ざ瘡が出現し た。 3 力月後には無月経, 血液検査上では高脂血症, 糖 尿病がみられステロイドの副作用と思われた。 ステロネ マの減量, 経ロステロイドへの変更を試みたが症状が再 燃し不可能であった。平成10年 8 月, ステロネマ継続中 にも関わらず再燃(中等症)した。平成10年10月, 副作用 のためステロイドの中止を患者本人が強く望んだため, 外科的治療, 白血球除去療法, 免疫抑制剂投与などの治 療法とともにレバミピド注腸療法の説明をした。レバミ ピド注腸に関しては，院内製剤による治験で，効果，副 作用ともに不明である旨を特に強調した。患者はレバミ ピド注腸を希望し，治験に同意し入院となった。

\section{3. 入院時現症}

身長 $159 \mathrm{~cm}$, 体重 $49.5 \mathrm{~kg}$, 体温 36.7 度, 意識は清明で あった. 血圧 $136 / 88 \mathrm{mmHg}$, 脈拍60/分・整, 呼吸20/分. 眼瞼結膜, 眼球結膜には異常は認めなかった. 胸部は聴 打診上特に異常認めず，腹部は平坦・軟で腸雑音は軽度 に艺進を認めた。顔面は満月様で, 後背部とともにざ瘡
が多数みられた。 入院時検査所見を表 3 に示した。炎症 所見では CRP $0.93 \mathrm{mg} / \mathrm{dL}$, 血沈 1 時間值 $15 \mathrm{~mm}$ と上昇 していたが, 白血球数は正常であった. 空腹時血糖153 $\mathrm{mg} / \mathrm{dL}, ク ゙ リ コ \mathrm{Hb}-\mathrm{A} 1 \mathrm{c} 7.6 \%$ と糖尿病が, また総コレ ステロール $287 \mathrm{mg} / \mathrm{dL}$, 中性脂肪 $192 \mathrm{mg} / \mathrm{dL}$ と高脂血症が みられ，これらはステロイドによる副作用と思われた。 便潜血は生化学法, 免疫法ともに陽性であった。便培養 では特に腸炎起因菌は検出されなかった。

\section{4. 注腸開始後の臨床経過}

レバミピド注腸開始後の臨床経過を図 4 に示した. 開 始時点で症状は 9 週間継続していた５-ASA，ステロ ネマは継続し，レバミピド注腸を開始した．投与開始直 後より症状の改善がみられ，2週後にはCRP の陰性化 がみられたためステロネマを中止したが再燃はみられ ず，血沈值も徐々に低下した．16週後には症状は消失 L, 白血球数, CRP 值, 血沈值も正常化し, 寛解と判 定した。催炎症性サイトカインである IL- 6 は症状, 炎 症所見の改善に伴い低下したが，抗炎症性サイトカイン である TGF- $\beta$ は相関しなかった。

開始前, 投与 8 週後, 16 週後の内視鏡像を図 5 に示し

表 3. 入院時開始時臨床検査成績

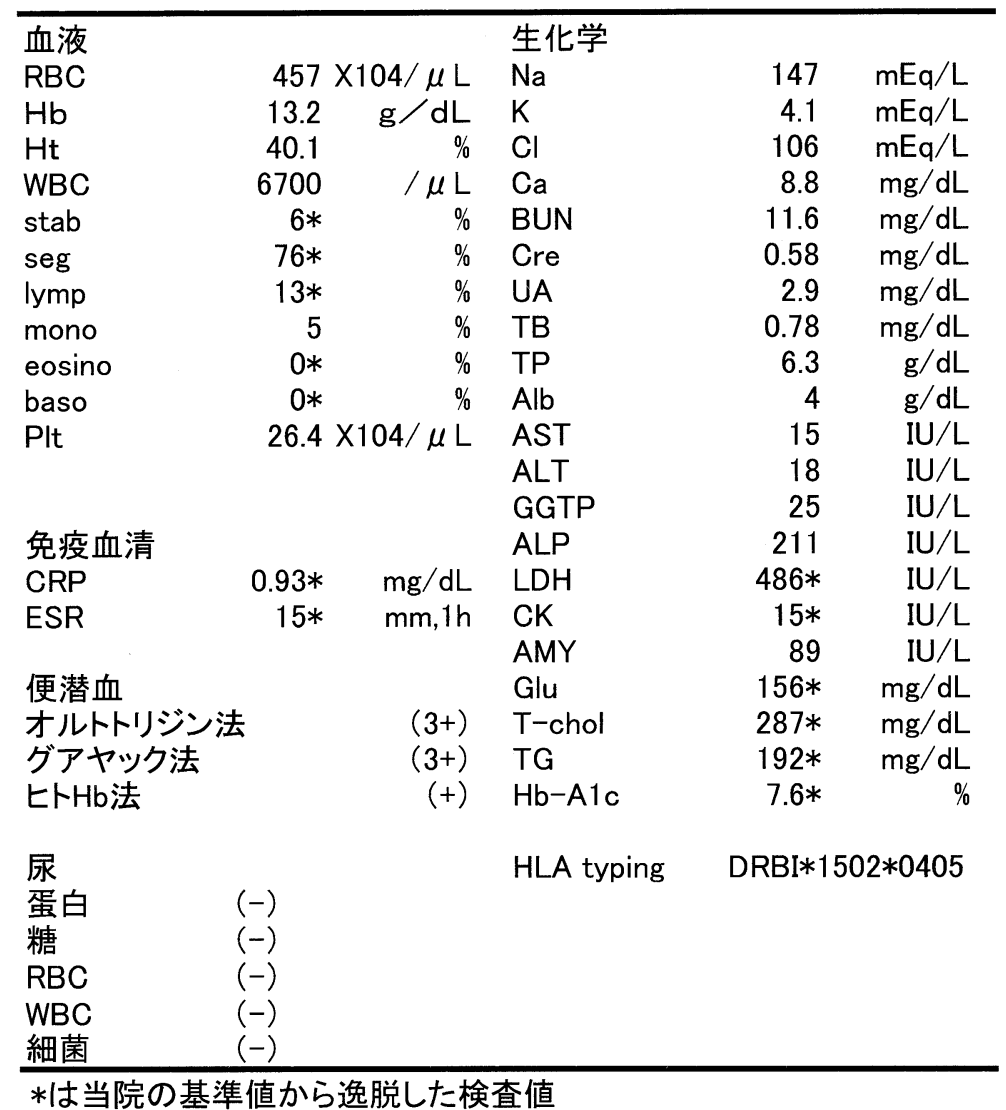

*は当院の基準值から逸脱した検査值 
やSASP およびステロイド剤が使用されている，UCは

た．開始前は粘膜面にびらんがみられ脆弱で易出血性で あったが，開始 8 週後にはびらん消失，脆弱性も改善 し，開始16週後には血管透見像も回復し，内視鏡的にも 著効を示し寬解状態となっていた。

\section{考察}

潰瘍性大腸炎は厚生労働省特定疾患に指定されてい る．原因が解明されていないこともあり，現在のところ 根治療法は外科的に大腸を摘出する以外にない. UC の 薬物療法の目的は，寛解への導入とその維持である，厚 生労働省の研究班によってその治療指針が示され，重症 度別に治療法が示されている. 基本治療薬として 5 -ASA
活動期になるとさまざまなサイトカイン，ロイコトリエ ン, プロスタグランジン, フリーラジカル, 血小板活性 化物質 PAF，プロテアーゼなどが産生される。基本治 療薬は主に炎症性物質の産生の抑制を目的としている。 寛解導入に用いられるステロイド剤には，感染症，糖尿 病，皮膚萎縮などの安全性に問題もあることから，副作 用が少なく，より安全に寛解導入に使用できる薬剤が求 められている。また既存の治療法では寛解せず，慢性持 続型の臨床経過を示す症例も存在し，治療の選択肢の拡 大が望まれている。

牧山らは中等症以上の症例にレバミピド注腸療法を試

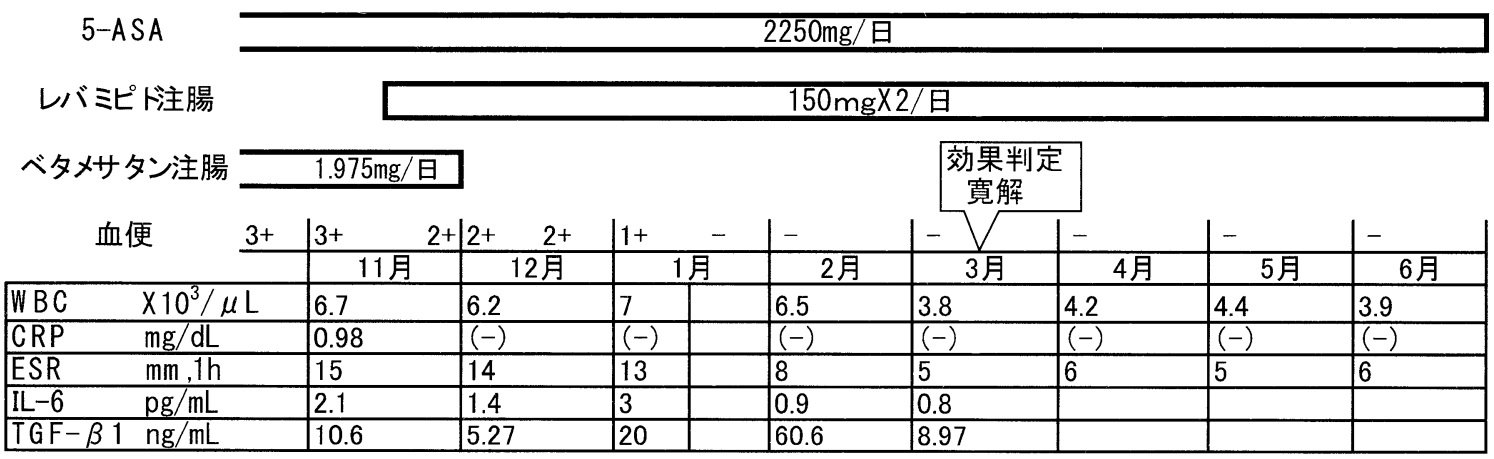

症状が9週間継続していたため、5-ASA、ステロネマを継続したままレバミピド注腸を開始した。

投与開始直後より症状の改善がみられ、2週後にはCRPの陰性化がみられたためステロネマを中止したが再燃はみられず、 血沈值も徐々に低下した。血便も同様に低下し、2力月後には陰性化した。16週後には症状は消失し、

白血球数、CRP值、血沈値も正常化し、寛解と判定した。IL-6は症状、炎症所見の低下に伴い低下したが、TGF- $\beta$ は相関しなかった。

\section{図 4. 臨床経過}

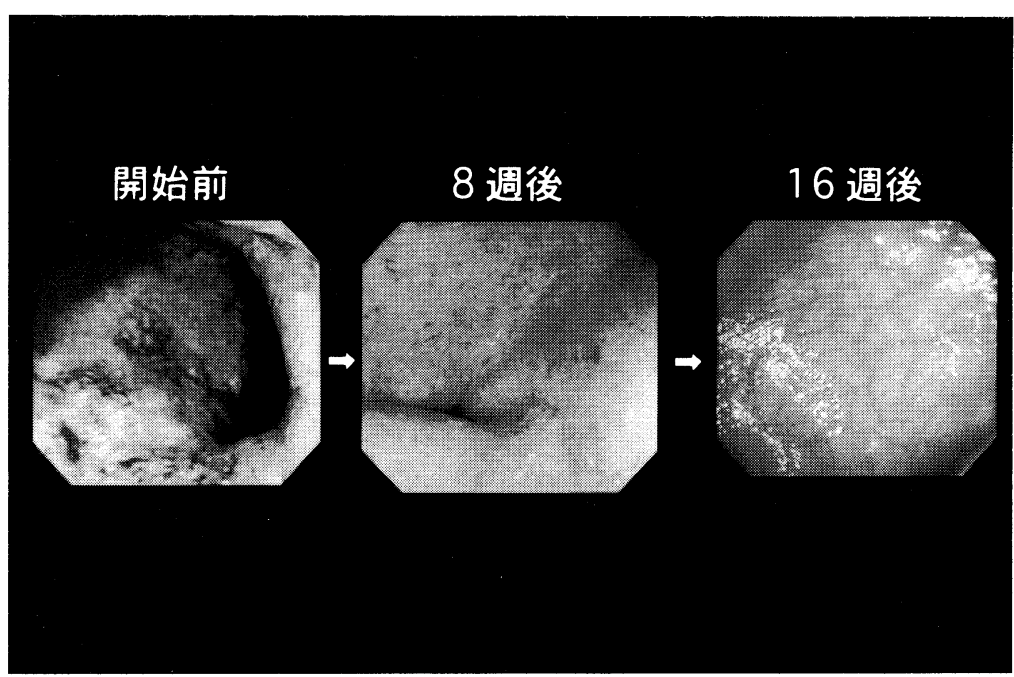

図 5.レバミピド注腸療法での内視鏡所見

開始前：粘膜面にびらんがみられ脆弱で易出血性であった

8 週後：びらん消失, 脆弱性も改善

16週後：血管透見度も回復，内視鏡的にも寛解状態となった 
み，内視鏡所見から明らかな有効性反応を認めたと報告 した7). 期待できる有効性は，(1)軽症～中等症の遠位大 腸炎，(2)ステロイド離脱のための併用療法に認められ る,としている.また抗酸化作用を有するレバミピドは, マウスに打けるDextran sulfate sodium(DDS)腸炎多や TNBS 腸炎年を抑制することが明らかにされている，今 回われわれは牧山らの報告5,7)に従ってレバミピド注腸 液を作製し，活動期のUCやステロイド剤の離脱に対 し, レバミピド注腸療法を試み, 宮田ら ${ }^{67}$ は今回提示し た症例をはじめとし, 多くの症例でその有効性を報告 し, 注目されている。レバミピドは経口投与しても吸収 率は約10\%と低く，その安全性はすでに確認されてい る. 注腸投与では直接潰瘍面と高濃度で接することによ り, 動物実験で示された炎症部位でのフリーラジカル消 去作用 ${ }^{3)}$ に加え，好中球の浸潤8) 粘膜内サブスタンス $\mathrm{P}$ 濃度の抑制 $\left.{ }^{9}\right), \quad \mathrm{COX}-2^{10)}$ の発現誘導あるいは炎症性サイ トカインの調節作用などが総合的に粘膜障害を防御する と考えられる。したがって本剤の注腸剤は，UCのステ ロイド療法の離脱に期待される新剤形の薬剤と考える.

一方, 院内製剂は安全性, 安定性が求められ, その品 質管理は薬郕師の重要な責務である。医師からの院内製 剤の申請に添付されている文献などは, 製剤の調製法, 臨床的有用性などについての記述はあるものの, 製剤後 の安定性のデー夕は少ない.レバミピドのインタビュー フォームにも溶液中の安定性試験の記載はないが, 原薬 の36週までの安定性試験の結果から，非常に安定である ことがうかがえた，今回われわれは，院内製戍の品質管 理上, レバミピド注腸液の経時的な安定性試験を試 み， 5 週間の期間に打いてその含有量に大きな変化はな く, 安定性に問題がないことが示された。 2 週間投与を 原則としていた投与日数も， 5 週間以内までに延長する ことができた，長期投与に伴い，注腸液は無菌操作で調 製し，オーエネマ60(テイコクメディックス侏)に 1 回 投与量を充填し, 安全性の確保に努めている。 またオー エネマ60を使用することで注腸操作が簡便となり患者の QOL の向上にも寄与できたと考える．今後は経時的に 無菌性，粘性の変化抒よび分散性について検討を加える 予定である.

\section{引用文献}

1）朝倉均, 潰瘍性大腸炎の概念, 診断基準, 分類, 日本臨床，57，2415-2419(1999).

2) M. Suzuki, S. Miura, M. Mori, A. Kai, H. Suzuki, D. Fukumura, M. Suematsu, M. Tsuchiya, Rebamipide, a novel antiulcer agent, attenuates Helicobacter pylori induced with neutrophil derived oxidants, Gut, 35, 1375-1378 (1994).

3) T. Yoshikawa, Y. Naito, T. Tanigawa, M. Kondo, Free radical scavenging activity of the novel antiulcer agent rebamipide studied electron spin resonance, Arzneim. Forsch. Drug Res., 43, 363-366 (1993).

4) W.L. Zea-Iriarte, K. Makiyama, K. Goto, Y. Urata, I. Sekine, K. Hara, T. Kondo, Impairment of antioxidants in colonic epithelial cells isolated from Trinitrobenzene sulphonic acid-induced colitis rats. Protective effect of rebamipide, Scand J. Gastroenterol, 31, 985-992(1996).

5) K. Makiyama, F. Takeshima, H. Kawasaki, W.L. ZeaIriarte, Anti-inflammatory effect of rebamipide enema on proctitis type ulcerative colitis : A novel therapeutic alternative, Am. J. Gastroenterol, 95, 1838-1839 (2000).

6）宮田充樹，春日井邦夫，各務伸一，下部限局性潰 瘍性大腸炎における Rebamipide 注腸療法の試み, “第88回日本消化器病学会総会抄録集”, 2002, S 5-10.

7）牧山和也, 竹島史直, 潰瘍性大腸炎に対する Rebamipide (antioxidant)の注腸療法の試み, 厚生科 学研究費補助金特定疾患対策研究事業「難治性炎 症性腸障害に関する調査研究」班, 分担研究報告 書, 164-165(2000).

8) S. Kishimoto, K. Haruma, A. Tari, K. Sakurai, M. Nakano, Y. Nakagawa, Rebamipide, an antiulcer drug, Prevents DDS-induced colitis formation in rats, Dig. Dis. Sci., 45, 1608-1616(2000).

9) S. Kishimoto, K. Hayashi, K. Sakurai, Involvement of substance $\mathrm{P}$ in the anti-inflammatory effect of rebamipide against dextran sulfate sodium-induced rat colitis, Gastroenterol, 116, A809(1999).

10) W.H. Sun, S. Tsuji, M.Tsuji, E.S. Gunawan, N. Kawai, A. Kimura, Y. Kakiuchi, M. Yasumaru, H. Iijima, Y. Okuda, Y. Sasaki, M. Hori, S. Kawano, Induction of cyclooxygenase -2 in rat gastric mucosa by rebamipide, a mucoprotective agent, J. Phrmaco. Ex. Ther., 295, 447-452(2000). 